\title{
Partial purification and characterisation of some low molecular weight $\alpha$ - amylases from Dolichos biflorus
}

\author{
M aryada Garg and A noop K . Dobriyal* \\ Department of Zoology, H.N.B. Garhwal Central University Campus, Pauri Garhwal-246001, Uttarakhand, INDIA \\ *Corresponding author. E-mail: anoopkdobriyal@ rediffmail.com
}

\begin{abstract}
Dolichos biflorus, a commonly used legume in Uttarakhand, produces alpha amylase enzyme for conversion of starch present in its cotyledons to glucose, so that this glucose can be further utilized for the life controlling processes, glycolysis and Kreb's cycle. Yield of this $\alpha$-amylase isolated from the germinating legume comes out to be $27.7 \mathrm{IUml}^{-1}$. Maximal amylase production occurs at $\mathrm{pH} 6.1$ at $45^{\circ} \mathrm{C}$. The enzyme was purified two fold, first with ultra-filtration and then with lon-exchange chromatography. Ultra-filtration revealed size of amylase to be between $10 \mathrm{kDa}$ and $30 \mathrm{kDa}$, against larger sizes of other bacterial amylases. The $\mathrm{pH}$ and temperature optima for purified enzyme were 6.1 and $45^{\circ} \mathrm{C}$ respectively. The $\mathrm{K}_{\mathrm{m}}$ for starch came out to be $1.95 \mathrm{mgml}^{-1}$. This finding of generating one more new and low-price source of $\alpha$-amylase is a great advancement in biotechnology.
\end{abstract}

Keywords: Ultra filtration, $\alpha$ - amylase, Yield, $\mathrm{K}_{\mathrm{m}}, \mathrm{V}_{\max }$

\section{INTRODUCTION}

Dolichos biflorus, commonly known as Kulath, is one of the most commonly used legumes in Uttarakhand Himalayan Region. Production of $\alpha$-amylase enzyme from germinating seedlings is a part and parcel of the life controlling processes of leguminous plants (Greenwood et al., 1965; Tripathi et al., 2007). Yield of amylase in germinating seedlings of this plant also comes out to be very high, as accounting to $27.7 \mathrm{IUml}^{-1}$, which simply proves that this plant source can be easily utilized in industry for extraction of this enzyme. Although many studies have been published on characterization of $\alpha$ amylase from a large number of sources (Warner and Knutson, 1991; Abe et al., 1994 ) but there is no literature regarding production of enzyme from $D$. biflorus. Considering low cost, enough cultivation, lacunae in literature on characterization of low molecular weight amylases from this plant, and to find out the possibility of its use on industrial scale, it was considered desirable to undertake the production, purification and characterization of $\alpha$-amylase from $D$. biflorus.

\section{MATERIALS AND METHODS}

The isolation of enzyme was performed following the method of Nirmala and Muralikrishna (2002). Six day old legumes of $D$. biflorus were used as source of enzyme. These legumes were crushed with mortar-pestle and filtered through four layers of cheese cloth. Then these were centrifuged at $13,000 \mathrm{rpm}$ for $10 \mathrm{~min}$. The supernatant which contain enzyme was collected and stored at $4{ }^{\circ} \mathrm{C}$. Enzyme assay was done by DNS method (Miller, 1959).
Substrate utilized for DNS method was glucose and the standard graph was plotted (Fig.1). One unit of enzyme was calculated as micromoles of glucose formed per $\mathrm{ml}$ of enzyme per unit time (in min) (Palmer, 2004). Enzyme activity is based on conversion of DNS to 3- amino 5nitro salicylic acid.

The supernatant was made to pass through $30 \mathrm{kDa}$ and $10 \mathrm{kDa}$ ultra filtration membrane respectively at $55 \mathrm{psi}$ pressure and $4^{\circ} \mathrm{C}$ temperature. Enzyme assays were performed with the ultra filtered extracts for calculating the percent recovery of $\alpha$-amylase in these extracts. This is accompanied with DNS method for quantitative estimation of the enzyme.

The ultrafiltered enzyme was further purified by column chromatography on DEAE cellulose (Welker and Campbell, 1967). The DEAE cellulose was washed with buffer $\mathrm{pH} 8$ and packed to a height of $5 \mathrm{~cm}$ in chromatographic column $2 \mathrm{~cm}$ in diameter. The DEAE cellulose was washed exhaustively with equilibration buffer $\mathrm{pH} 8$ and the $\alpha$-amylase solution was applied to the column. The $\alpha$-amylase was eluted by stepwise elution with increasing molarities of sodium phosphate buffer $(0.05,0.1,0.15,0.2,0.25,0.3,0.4$ and $0.5 \mathrm{M}) \mathrm{pH} 7.2$. The fractionation was carried out at $4{ }^{\circ} \mathrm{C}$ and the eluate was collected in 2-2 ml fractions. Each fraction was assayed for enzyme activity. The fraction showing maximum amylase activity was further subjected to kinetic characterization.

The purified enzyme was characterized for its optimum $\mathrm{pH}$, temperature, time and substrate concentration. All assays were performed by DNS method using starch as 


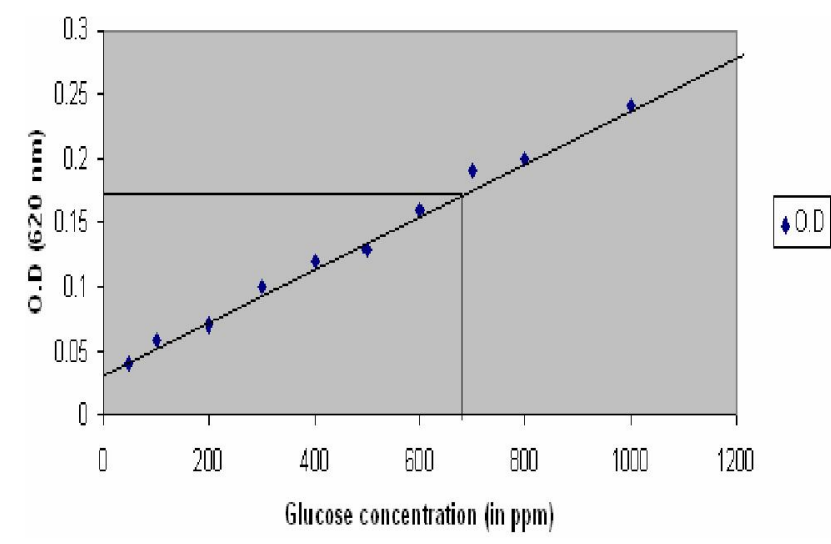

Fig. 1. Standard graph showing enzyme activity of crude enzyme.

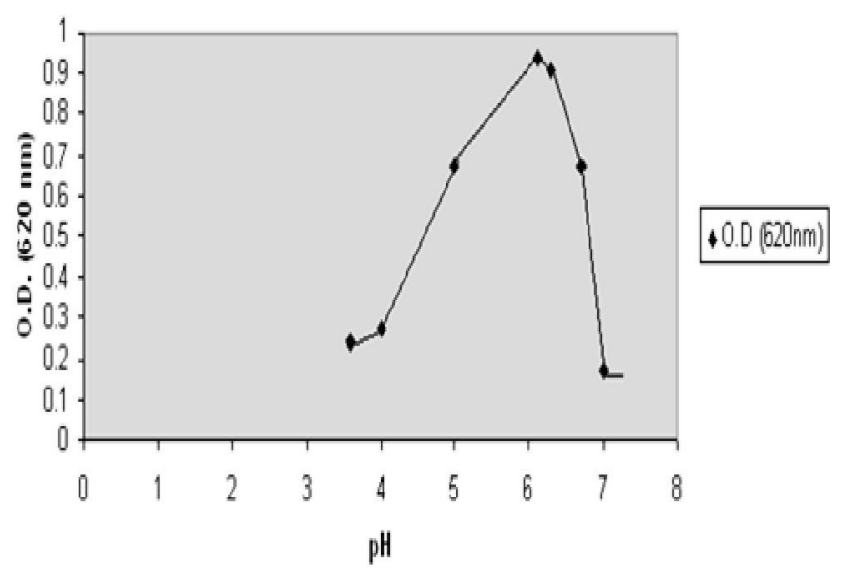

Fig. 2. G raph showing optimum pH of crude enzyme of kulath.

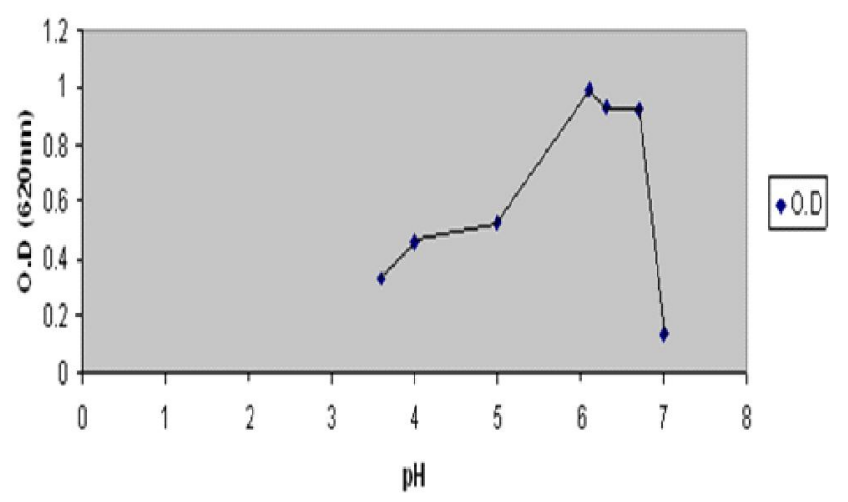

Fig. 3. Graph showing optimum $\mathrm{pH}$ of purified alpha amylase of kulath.

substrate. Finally $\mathrm{K}_{\mathrm{m}}$ and $\mathrm{V}_{\text {max }}$ were determined.

\section{RESULTS AND DISCUSSION}

Standard graph was obtained as a straight line graph which followed Beer- Lambert's law. Optical density of crude enzyme (620 nm) at pH 7 came out to be 0.17 . From the standard graph, corresponding glucose concentration was calculated to be $680 \mathrm{mgl}^{-1}$. The total enzyme activity at $\mathrm{pH} 7$ was calculated as $3.78 \mathrm{IUml}^{-1}$. The optimum $\mathrm{pH}$ of this crude extract was found out to be 6.1. A bell shaped graph was obtained, as shown in Fig. 2. Purification: Optical density of $30 \mathrm{kDa}$ ultra filtered extract was found out to be 0.13 , for which enzyme yield came out to be $2.77 \mathrm{IUml}^{-1}$. As the crude extract contained $3.78 \mathrm{IUml}^{-1}$ enzymes so, it was deduced that nearly $2 / 3$ of $\alpha$-amylase of this plant is below $30 \mathrm{kDa}$ size. These results confirmed earlier results of Nirmala and Muralikrishna (2002) who showed the size of cereal $\alpha$-amylases to be $22 \mathrm{kDa}$. In $10 \mathrm{kDa}$ extract no enzyme activity was found $(\sim 0.02)$, thus it was deduced that the size of this $\alpha$-amylase is between $10 \mathrm{kDa}$ to $30 \mathrm{kDa}$. Highly purified $\alpha$-amylase was eluted at $250 \mathrm{mM}$ concentration. This amylase shows yield of $27.7 \mathrm{IUml}^{-1}$

Effect of $\mathrm{pH}$ and temperature on the purified enzyme: The crude extract was found to have $\mathrm{pH}$ optima of 6.1. A bell shaped graph was obtained again (Fig. 3). The enzyme showed maximum activity between $\mathrm{pH} 5.5$ to 7 . But the activity reduced in alkaline range i.e $>7$.The drop in activity was more in phosphate buffer than in Tris- $\mathrm{HCl}$ buffer, indicating the stability of enzyme in Tris- $\mathrm{HCl}$ buffer. After $\mathrm{pH} 7.5$, the enzyme activity almost nullified. These results correspond with previous results of Nirmala and Muralikrishna (2002).

To determine the temperature optima of kulath $\alpha$-amylase, the activities were determined at temperature range 0 $80^{\circ} \mathrm{C}$. A slightly distorted bell shaped graph was obtained (Fig. 4). The optimum temperature of enzyme was found at $45^{\circ} \mathrm{C}$. The enzyme showed best stability in temperature range $42-48^{\circ} \mathrm{C}$ and above $75^{\circ} \mathrm{C}$ it was found to be totally unstable. This high thermal stability of the enzyme accounts to more and more industrial usage.

$\mathrm{K}_{\mathrm{m}}$ and $\mathrm{V}_{\mathrm{Max}}$ : Enzyme activity of the enzyme was checked at various substrate concentrations of starch. A graph was plotted taking substrate concentration (So) on Xaxis and Enzyme activity (Vo) on Y-axis. A slightly distorted parabolic graph obeying Michaelis- Menton equation was obtained (Fig. 5). The enzyme activity first increased very slowly and then after increasing substrate concentration to $2 \mathrm{mgml}^{-1}$, it suddenly increased 4 times. $\mathrm{V}_{\text {max }}$ was obtained at $28 \mathrm{IUml}^{-1}$. From the graph, $\mathrm{K}_{\mathrm{m}}$ was calculated as $1.95 \mathrm{mgml}^{-1}$.

Some reports are already available on the extraction of $\alpha$ amylase from pulse crops like mung beans, soyabean

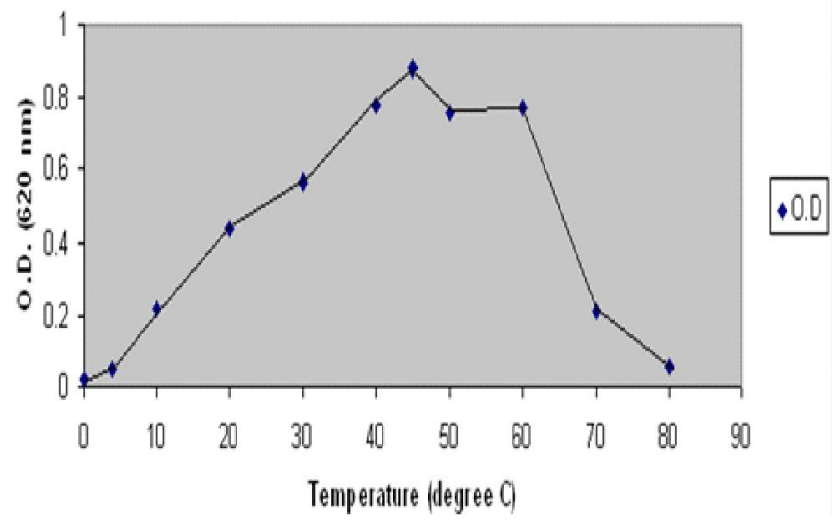

Fig. 4. Graph showing optimum temperature of purified enzyme in kulath. 


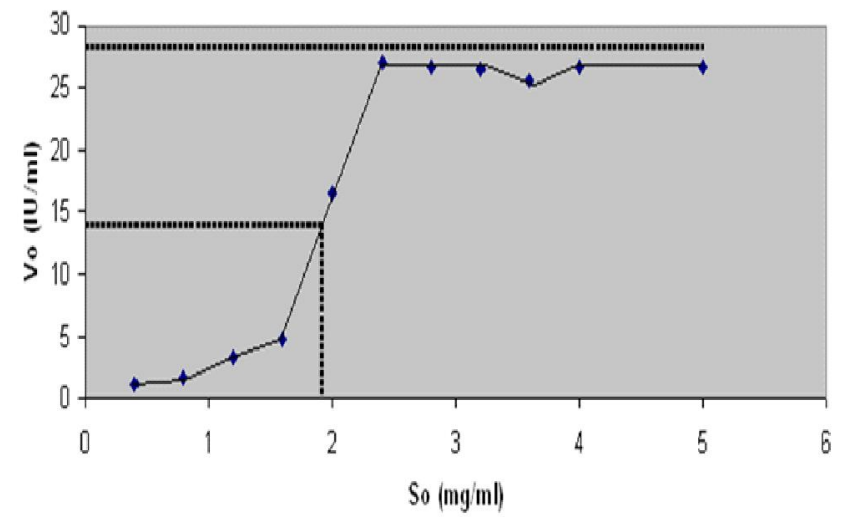

Fig. 5. Graph showing So against Vo.

and pea etc. (Greenwood et al., 1965; Beers and Duke, 1988; Tripathi et al., 2007). Kapoor (2005) has shown the presence of urease enzyme in $D$. biflorus. The present report is first attempt on the extraction of $\alpha$-amylase from $D$. biflorus. The seeds of this plant have high medicinal importance as an astringent to bowels, antipyretic, diuretic, tonic, antihelminthic, appetizing and lithontriptic. It is useful in piles, tumours, bronchitis, heart trouble, kidney stone, enlargement of spleen, hiccough, asthma, leucoderma, and in abdominal complaints (Kapoor, 2005). The thought, that this pulse of immense medicinal importance must have certain other enzymes, was also an inspiration behind present study.

\section{REFERENCES}

Abe, J., Onitsuka, N., Nakano, T., Shibata, Y., Hizukuri, S., and Entani, E. (1994). Purification and characterisation of periplasmic $\alpha$-amylase from Xanthomonas campestris $\mathrm{K}$ 11151. J ournal of Bacteriology, 176 (12): 3584-3588.

Beers, E.P and Duke, S.H (1988). Localisation of alpha-amylase in apoplast of Pea (Pisum sativum L) Stems. Plant physiology, 87(4): 799-802.

Greenwood, C.T.., MacGregor, A.W. and Milne, E.A. (1965). Studies on starch-degrading enzymes: Part II. The Z-enzyme from soya beans; purification and properties. Carbohydrate Research, 1(3):229-241.

Kapoor, L. D. (2005). Handbook of ayurvedic medicinal plants. CRC Press LLC, Boca Raton, Florida. 167-168.

Miller, G. L (1959). Use of dinitrosalicylic acid reagent for determination of reducing sugar. A nalytical C hemistry, 31(3): 426-428.

Nirmala, M. and Muralikrishna, G. (2002). Three $\alpha$-amylases from malted finger millet (Ragi, Eleusine cor acana, Indaf15) - purification and partial characterization. Phytochemistry, 62: 21-30.

Palmer, T. (2004). Enzymes-Biochemistry, Biotechnology, Clinical Chemistry Published by: Affiliated East-West Press Private Ltd., New Delhi, I Edition: 282-283.

Tripathi, P., Leggio, L.L., Johanna J. Mansfeld, R. UlbrichHofmann, A.M. Kayastha (2007). $\alpha$-amylase from mung beans (Vigna radiata) - correlation of biochemical properties and tertiary structure by homology modeling. Phytochemistry, 68: 1623-1631.

Warner, D.A. and Knutson, C.A. (1991). Isolation of $\alpha$ amylases and other starch degrading enzymes from endosperm of germinating maize. PlantScience, 78(2):143-150. Welker, N.E. and Campbell, L.L. (1967). Comparison of $\alpha$ amylase of $B$ acillus subtilis and Bacillus amyloliquefaciens. J ournal of Bacteriology, 94(4):1131-1135. 